\title{
Ig $G_{4}$-subclass of glutamic acid decarboxylase antibody is more frequent in latent autoimmune diabetes in adults than in type $\mathbf{1}$ diabetes
}

\author{
M. Hillman ${ }^{1}$ C. Törn ${ }^{1}$ - H. Thorgeirsson ${ }^{1}$ - M. Landin-Olsson ${ }^{1}$ \\ ${ }^{1}$ Institution of Medicine, Lund University Hospital, Diabetes Research Laboratory, Lund University, Lund, Sweden
}

\begin{abstract}
Aims/hypothesis. Glutamic acid decarboxylase autoantibodies (GADA) are the most frequent beta-cell-specific autoantibodies in type 1 diabetes and in latent autoimmune diabetes in adults (LADA). The autoimmune attack on pancreatic islet cells is associated with a $T$ helper 1 cell $\left(T_{h} 1\right)$ response, mainly represented by $\mathrm{IgG}_{1}$-subclass in humans. It has been proposed that the presence of $\operatorname{IgG}_{4}$ may be associated with a $\mathrm{T}_{\mathrm{h}} 2$ response. The aim of our study was to compare the GADA IgG-subclass distribution between adult patients with type 1 diabetes and LADA.

Methods. Patients with type 1 diabetes $(n=45)$ and patients with LADA $(n=60)$ were included. Radioimmunoprecipitation assay with IgG-subclass specific Sepharose $\left(\mathrm{IgG}_{1}, \mathrm{IgG}_{2}, \mathrm{IgG}_{3}\right.$ and $\left.\mathrm{IgG}_{4}\right)$ was used to precipitate the antibody/antigen-complex.
\end{abstract}

Results. We only detected $\operatorname{IgG}_{4}$-subclass of GADA in subjects with LADA $(26.7 \% ; p<0.001) . \mathrm{IgG}_{1}$ was the most common GADA-subclass in both groups, however $\mathrm{IgG}_{1}$ as the solely expressed subclass was more common among type 1 diabetic patients $(77.8 \% ; p<0.05)$. The rank order of the frequencies of $\mathrm{IgG}$-subclasses in type 1 diabetes was $\operatorname{IgG}_{1}>\operatorname{IgG}_{3}>\operatorname{IgG}_{2}>\mathrm{IgG}_{4}$ and in LADA patients $\mathrm{IgG}_{1}>\mathrm{IgG}_{4}>\mathrm{IgG}_{2}>\mathrm{IgG}_{3}$.

Conclusions/interpretation. The difference in GADA IgG-subclasses could indicate a different immune response, possibly an altered balance between $\mathrm{T}_{\mathrm{h}} 1$ and $\mathrm{T}_{\mathrm{h}} 2$ cytokine profile in pancreatic islets. This difference could contribute to the slower rate of beta cell destruction in LADA patients, as reflected by a higher C-peptide level at clinical onset.

Keywords Diabetes mellitus - GAD65 enzyme · Immunoglobulin $\mathrm{G} \cdot$ Radioimmunoprecipitation assay

\section{Introduction}

Autoantibodies directed against glutamic acid decarboxylase (GADA) and beta-cell-specific tyrosine

Received: 31 March 2004 / Accepted: 18 July 2004

Published online: 24 November 2004

C) Springer-Verlag 2004

\author{
M. Hillman ( \\ Institution of Medicine, Lund University Hospital, \\ Diabetes Research Laboratory, Lund University, \\ B11, BMC, 22184 Lund, Sweden \\ E-mail: Magnus.Hillman@med.lu.se \\ Tel.: +46-46-2220705, Fax: +46-46-2114513
}

Abbreviations: GADA, autoantibodies against glutamic acid decarboxylase · IA-2, islet antigen 2 (beta-cell-specific tyrosine phosphatase) $\cdot$ LADA, latent autoimmune diabetes in adults $\cdot \mathrm{T}_{\mathrm{h}} 1, \mathrm{~T}$ helper cell $1 \cdot \mathrm{T}_{\mathrm{h}} 2, \mathrm{~T}$ helper cell 2 phosphatase (IA-2A) are frequently found in patients with type 1 diabetes mellitus and latent autoimmune diabetes in adults (LADA). Patients with LADA have a slower progression of beta cell destruction than patients with type 1 diabetes, which is reflected by the higher C-peptide levels found at diagnosis in LADA patients [1]. The phenotype of LADA tends to resemble classical type 2 diabetes, with patients older at clinical onset, with higher BMI, no initial requirement of insulin treatment and more pronounced insulin resistance [2]. Somehow the beta cell destruction in LADA seems to be less aggressive than in type 1 diabetes. The genetics of LADA and type 1 diabetes with onset in adulthood are similar according to the HLAsystem [3], even though patients with LADA have a lower frequency of risk genes than patients diagnosed with type 1 diabetes in childhood [4]. Another difference between LADA and type 1 diabetes is that 
Table 1. Clinical characteristics of adult patients with type 1 diabetes (T1DM) and patients with latent autoimmune diabetes in adults (LADA) at clinical onset

\begin{tabular}{llll}
\hline & T1DM $(n=45)$ & LADA $(n=60)$ & $p$ \\
\hline Age: median; range (years) & $31 ; 16-67$ & $49 ; 23-80$ & $<0.01$ \\
C-peptide: median; range (nmol/l) & $0.28 ; 0.13-0.98^{*}$ & $0.57 ; 0.19-2.3^{\mathrm{a}}$ & $<0.01$ \\
Duration: median; range (days) & $2 ; 0-39$ & $2 ; 0-114$ & $\mathrm{NS}$ \\
Men/women & $28 / 17$ & $28 / 32$ & $\mathrm{NS}$ \\
BMI: median; range $\left(\mathrm{kg} / \mathrm{m}^{2}\right)$ & $22 ; 17-27^{\mathrm{b}}$ & $26 ; 18-47^{\mathrm{c}}$ & $<0.01$ \\
\hline
\end{tabular}

$*_{n=42,{ }^{\mathrm{a}} n=55 ;{ }^{\mathrm{b}} n=31 ;{ }^{\mathrm{c}} n=39}$

LADA patients are more often positive for a single autoantibody, while patients with type 1 diabetes mostly have several autoantibodies $[5,6]$.

It is possible that the immune system responds differently in the two forms of autoimmune diabetes. Type 1 diabetes is associated with a $\mathrm{T}$ helper 1 cell $\left(\mathrm{T}_{\mathrm{h}} 1\right)$ cytokine profile $[7,8,9]$, in which $\operatorname{IgG}_{1}$ is the dominating GADA-subclass in humans $[8,10]$. In mice beta cell destruction is related to a $T_{h} 1$-associated response [11], which is associated with the production of IFN- $\gamma$, TNF and IL-2, but also with the generation of $\mathrm{IgG}_{2 \mathrm{a}}$ and $\mathrm{IgG}_{3}$ [12]. $\mathrm{IgG}_{4}$ is more likely to appear together with the cytokines IL-4, IL-5 and IL-13, which are related to a $T_{h} 2$ response $[12,13,14]$. Our hypothesis is that the profile of IgG-subclasses will reflect the relative balance of $\mathrm{T}$ cell subsets and degree of immunogenicity in the destructive process.

The aim of our study was to determine the IgGsubclasses of GADA in patients with type 1 diabetes and LADA and compare the IgG-subclass profile as a reflection of $\mathrm{T}$ helper cell response against beta-cellspecific antigens in the two types of autoimmune diabetes.

\section{Subjects and methods}

Subjects. Subjects included in this study were clinically classified by the treating physician as having either type 1 or type 2 diabetes. Type 2 diabetic patients with antibody positivity for either one of GADA, islet cell antibody or IA-2 were considered to have LADA. All the patients were above 15 years of age at clinical onset and were diagnosed between 1995 and 2001 in former Malmöhus läns landsting, southern Sweden. The plasma samples were collected as close to diagnosis as possible (clinical data, see Table 1). A control group ( $n=119$; median age 30 years; range 19-65 years) consisting of healthy blood donors was used to determine the cut-off level for the respective IgG-subclass. All control subjects signed a form giving informed consent. This study was approved by the Ethical committee at Lund University (LU-44-95 and LU-526-00).

Analysis of IgG-subclass antibodies. Plasma from the subjects was incubated with in vitro translated recom- binant $65 \mathrm{M}_{\mathrm{r}} \mathrm{GAD}_{65}$ labelled with ${ }^{35} \mathrm{~S}$-methonine (20-7149-50, Amersham Biosciences Europe, Freiburg, Germany). Total GADA was analysed with a radioimmunoprecipitation assay [15]. The sensitivity and specificity of this method are $81 \%$ and 95\% respectively [16]. Biotin-conjugated antibodies directed against specific human IgG-subclasses $\left(\mathrm{IgG}_{1}[35052 \mathrm{D}], \quad \mathrm{IgG}_{2}[35072 \mathrm{D}], \mathrm{IgG}_{4}[35092 \mathrm{D}] ; \mathrm{BD}\right.$ Biosciences, PharMingen, San Diego, Calif., USA; $\mathrm{IgG}_{3}[05-3640]$, Zymed Laboratories, San Francisco, Calif., USA) were incubated with streptavidin Sepharose high performance (17-5113-01; Amersham Biosciences Europe) to form a specific IgG-subclass Sepharose. The plasma was incubated with the IgG-subclass-specific Sepharose at $4{ }^{\circ} \mathrm{C}$ for 90 minutes, washed and dried before the counts per minute (cpm) were measured in a beta counter. Quadruplicates of inhouse positive and negative standards and duplicates of each sample were used. The results were expressed as indexes to compensate for background radiation and were calculated in the following way:

Mean Count Sample $(\mathrm{cpm})$
$\frac{- \text { Mean Count Negative Std }(\mathrm{cpm})}{\text { Mean Count Positive Std }(\mathrm{cpm})}=$ INDEX
- Mean Count Negative Std $(\mathrm{cpm})$

where Std stands for standard.

The upper limit for negativity for $\operatorname{IgG}_{1}$ was an index of 0.04 , for $\operatorname{IgG}_{2}$ an index of 0.12 , for $\operatorname{IgG}_{3} 0.11$, and for $\mathrm{IgG}_{4}$ an index of 0.06 , and was calculated as mean +3 standard deviations. The inter-assay variation coefficients were determined as $19 \%$ for $\mathrm{IgG}_{1}$, $17 \%$ for $\mathrm{IgG}_{2}, 24 \%$ for $\mathrm{IgG} 3$ and $21 \%$ for $\mathrm{IgG}_{4}$. The intra-assay variations for each subclass were determined as $10 \%$ for $\operatorname{IgG}_{1}, 6 \%$ for $\operatorname{IgG}_{2}, 13 \%$ for $\operatorname{IgG}_{3}$ and $12 \%$ for $\mathrm{IgG}_{4}$.

Analysis of C-peptide. We analysed C-peptide using a commercial radioimmunoassay kit (Euro-Diagnostica, Malmö, Sweden) at the Department of Clinical Chemistry, University Hospital of Lund, Sweden. The intraassay variation was $5 \%$ in the measurement interval 0.5-3.5 mmol/l and total variation (sum of intra- and inter-assay variation) was $7 \%$ in the same measurement interval. The detection limit was $0.13 \mathrm{nmol} / \mathrm{l}$ and 
Table 2. Frequencies of IgG-subclasses against $\mathrm{GAD}_{65}$ in newly diagnosed patients with latent autoimmune diabetes in adults (LADA) or type 1 diabetic patients (T1DM)

\begin{tabular}{lcrc}
\hline GADA-subclass & T1DM $(n=45), n(\%)$ & LADA $(n=60), n(\%)$ & $p$ \\
\hline $\mathrm{IgG}_{1}$ & $43(95.6)$ & $52(86.7)$ & $\mathrm{NS}$ \\
$\mathrm{IgG}_{2}$ & $5(11.1)$ & $8(13.3)$ & $\mathrm{NS}$ \\
$\mathrm{IgG}_{3}$ & $6(13.3)$ & $6(10.0)$ & $\mathrm{NS}$ \\
$\mathrm{IgG4}$ & 0 & $16(26.7)$ & $<0.001$ \\
\hline
\end{tabular}

Table 3. IgG-subclass combinations against $\mathrm{GAD}_{65}$ in newly diagnosed Swedish patients with type 1 diabetes (T1DM) or latent autoimmune diabetes in adults (LADA)

\begin{tabular}{|c|c|c|c|}
\hline GADA-subclass combination & $\begin{array}{l}\text { T1DM }(n=45) \\
n(\%)\end{array}$ & $\begin{array}{l}\text { LADA }(n=60) \\
n(\%)\end{array}$ & $p$ \\
\hline $\mathrm{IgG}_{1}$ only & $35(77.8)$ & $35(58.3)$ & 0.04 \\
\hline $\mathrm{IgG}_{1}$ and $\mathrm{IgG}_{3}$ & $3(6.7)$ & $1(1.7)$ & NS \\
\hline $\mathrm{IgG}_{1}$ and $\mathrm{IgG}_{4}$ & 0 & $7(11.7)$ & 0.019 \\
\hline $\mathrm{IgG}_{1}, \mathrm{IgG}_{2}$ and $\mathrm{IgG}_{3}$ & $3(6.7)$ & 0 & NS \\
\hline $\mathrm{IgG}_{1}, \mathrm{IgG}_{2}, \mathrm{IgG}_{3}$ and $\mathrm{IgG}_{4}$ & 0 & $4(6.7)$ & NS \\
\hline Not detectable & $2(4.4)$ & $8(13.3)$ & NS \\
\hline
\end{tabular}

the reference interval was $0.25-1.0 \mathrm{nmol} / \mathrm{l}$. Some of the patients were analysed in the fasting state, while others were analysed after eating. However, there is no marked difference in fasting and non-fasting $\mathrm{C}$ peptide levels in patients with autoimmune diabetes [17].

Statistical methods. The antibody status, age and type of diabetes were analysed by the statistical package for social sciences (SPSS for Windows version 11.5; SPSS, Chicago, Ill., USA) and Statistics for Biomedical Research (MedCalc for Windows version 7.2). Differences between frequencies were estimated with the chi square test or fisher's exact test. Differences in autoantibody levels between groups were compared with the Mann-Whitney $U$ test. The Spearman rank correlation test $\left(r_{s}\right)$ was used to test for correlations in levels. Results were considered significant when twosided $p$ values were less than 0.05 .

\section{Results}

$\mathrm{IgG}_{4}$ was the second most frequent subclass detected in LADA patients $(26.7 \%)$ while it was not detected at all in patients with type 1 diabetes $(p<0.001)$ (Table 1; Fig. 1). The rank order of the frequency of GADA IgG-subclasses in LADA patients was $\mathrm{IgG}_{1}>\mathrm{IgG}_{4}>\mathrm{IgG}_{2}>\mathrm{IgG}_{3}$, whereas in patients with type 1 diabetes it was $\operatorname{IgG}_{1}>\operatorname{IgG}_{3}>\operatorname{IgG}_{2}>\operatorname{IgG}_{4}$. The distribution of $\mathrm{IgG}_{2}$ and $\mathrm{IgG}_{3}$ was similar in both groups (10.0-13.3\%) (Table 2). $\mathrm{IgG}_{1}$ was the most frequently occurring subclass in GADA-positive patients in both groups, found in $83.3 \%(50 / 60)$ of the patients with LADA and in $95.6 \%(43 / 45 ; p=\mathrm{NS})$ (Table 2) of the patients with type 1 diabetes. When $\mathrm{IgG}_{1}$ was the only subclass, it was less common in patients wih LADA $(56.7 \%, 34 / 60)$ than in those with type 1 diabetes $(77.8 \%, 35 / 45 ; p<0.05)$ (Table 3). There was no significant difference in total GADA between LADA patients (median 0.77; range $0.2-1.47$ ) and type 1 diabetic patients (median 0.78 ; range $0.08-1.61$ ).

Most patients with type 1 diabetes expressed $\operatorname{IgG}_{1}$ only, and only $17.8 \%$ (8/45) of them had several subclasses of GADA IgG, compared to $28.3 \%$ (17/60) of patients in the LADA group (Table 2). This was mostly due to the higher frequency of $\mathrm{IgG}_{4}$ in LADA patients, 16 of whom were $\mathrm{IgG}_{4}$-positive.

Some patients had very low concentrations of GADA antibodies when analysed with our standard method for total GADA IgG. Consequently, in $4.4 \%$ $(2 / 45)$ of the type 1 diabetic and in $13.3 \%(8 / 60)$ of the LADA patients, IgG-subclasses were not detectable (Table 3).

The C-peptide levels were higher in patients with LADA $\quad(n=56 ;$ median $0.57 \mathrm{nmol} / \mathrm{l}$; range $0.14-1.80 \mathrm{nmol} / \mathrm{l})$ than in patients with type 1 diabetes ( $n=45$; median $0.28 \mathrm{nmol} / \mathrm{l}$; range $0.13-2.50 \mathrm{nmol} / \mathrm{l}$; $p<0.001)$. Patients with LADA also had a higher median age (see Subjects). However, in $\mathrm{IgG}_{4}$-positive patients there was no correlation either between the levels of $\mathrm{IgG}_{4}$ and C-peptide $\left(r_{s}=-0.148 ; p=\mathrm{NS}\right)$ or between $\mathrm{IgG}_{4}$ and age $\left(r_{s}=0.374 ; p=\mathrm{NS}\right)$. 


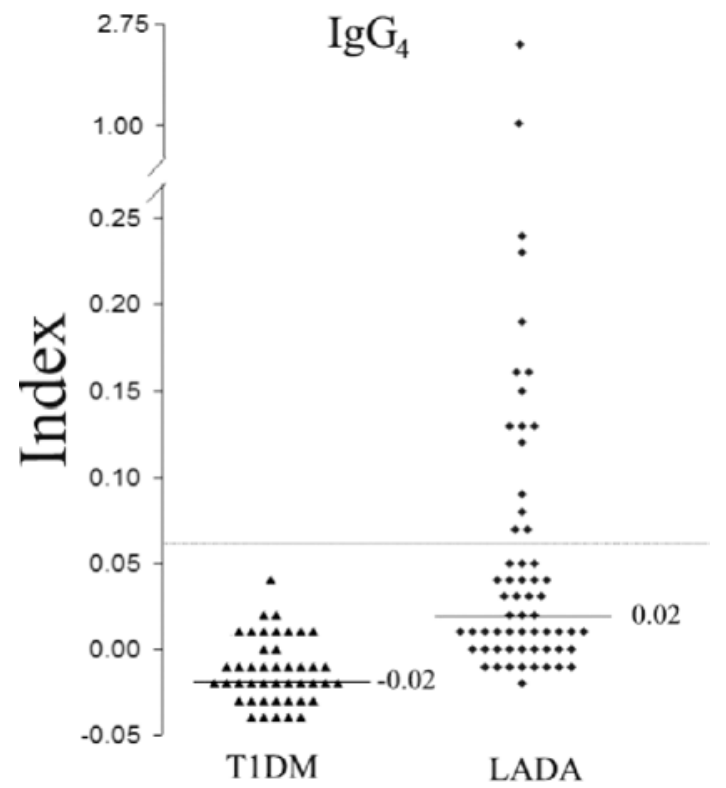

Fig. 1. GADA $\operatorname{IgG}_{4}-$ subclass distribution in patients with type 1 diabetes (T1DM; $n=45)$ and in patients with latent autoimmune diabetes in adults (LADA; $n=60$ ). $\mathrm{IgG}_{4}$ directed against $\mathrm{GAD}_{65}$ was found in 16 patients with LADA while this subclass was not detected at all in patients with type 1 diabetes $(p<0.001)$. Patients with an index below -0.05 are not shown in the figure. The cut-off level for negativity was fixed at 0.06 (represented by a dotted line). The median index levels in each group are shown in the figure as -0.02 for type 1 diabetes and 0.02 for LADA

\section{Discussion}

We found that the $\mathrm{IgG}_{4}$-subclass of GADA was more prevalent in LADA patients than in adult patients with type 1 diabetes, with $\mathrm{IgG}_{4}$ found in about $30 \%$ of the former, but being absent in type 1 diabetic patients. However, when $\mathrm{IgG}_{4}$ was found, it was always co-expressed with $\mathrm{IgG}_{1}$-subclass. $\mathrm{IgG}_{1}$ was detected in all (i.e. type 1 and LADA) patients in whom subclasses were identified.

To our knowledge, the present study is the largest one to analyse IgG-subclass against $\mathrm{GAD}_{65}$ in LADA patients and in adult type 1 diabetic patients. The method used, however, has not yet been subjected to international standardisation. Previous studies on IgGsubclasses against GAD and IA-2A have been done in type 1 diabetic patients and in autoantibody-positive first degree relatives of such patients [7, 8, 10, 13, 18], but only limited data from LADA patients have been reported [10]. Since both GAD $_{65}$ and IA-2 are expressed in beta cells and exposed to the same immune cells, the isotype restriction can be expected to be similar. IA-2A restricted to the $\mathrm{IgG}_{4}$-subclass have been shown to be associated with protection from type $1 \mathrm{di}-$ abetes [18] and GADA $\operatorname{IgG}_{4}$ have been shown to be associated with slower progression to clinical diabetes [8], as our study confirms. GADA $\mathrm{IgG}_{4}$ have also been found in pre-diabetic patients and individuals with non-progressing diabetes [10,13], corresponding with the milder T cell response that is thought to occur in these subjects.

In contrast to our finding that $\mathrm{GADA}_{\mathrm{IgG}}$ was detectable only in LADA patients, this subclass has previously been found in early type 1 diabetes $[8,10,13]$. This could be explained by the possible influence of different methods on the finding of $\mathrm{IgG}_{4}$ in low titres. One study showed that $90 \%$ of Chinese type 1 diabetic patients exhibited two or more IgG-subclasses directed against IA-2 [19], while we found that it was more common for patients with type 1 diabetes to express GADA $\mathrm{IgG}_{1}$ only.

In some patients (two in the type 1 diabetes group and eight in the LADA group) IgG-subclasses were not detected at all, even though all the patients with non-detectable GADA IgG-subclasses had low titres of total GADA (index 0.08-0.19; limit for negativity $<0.08$ ). This might be explained by the presence of many different subclasses in levels below the detection limit.

In mice, IFN- $\gamma$ and IL- 2 from $\mathrm{T}_{\mathrm{h}} 1$ lymphocytes stimulate the production of $\mathrm{IgG}_{2 \mathrm{a}}$ and $\mathrm{IgG}_{3}$, whereas IL-4 and IL-10 from $\mathrm{T}_{\mathrm{h}} 2$ lymphocyte stimulates the synthesis of $\operatorname{IgG}_{1}$ and $\operatorname{IgG}_{2 b}[7,11]$. In humans there is no well-defined relation between $\mathrm{IgG}_{2}$ and $\mathrm{IgG}_{3}$ and specific $\mathrm{T}$ cell subsets or cytokines. However, it has been suggested that $\mathrm{IgE}$ and $\mathrm{IgG}_{4}$ are associated with a $\mathrm{T}_{\mathrm{h}} 2$-response $[7,13]$. Therefore, results from animal experiments cannot be used directly to interpret findings in human subjects and we cannot conclude whether the immune response in human diabetes is $\mathrm{T}_{\mathrm{h}} 1$ - or $\mathrm{T}_{\mathrm{h}}$ 2-related merely on the basis of the IgGsubclass distribution. One way of further clarifying the results would be to measure the cytokine concentrations, as well, but this would have to be performed in the local organ, since analyses in sera or plasma do not elucidate where the cytokines originate. $T_{h} 1$ and $\mathrm{T}_{\mathrm{h}} 2$ coexist in the same individual [20] and may influence cytokine findings in blood. For example, a virus infection that is $\mathrm{T}_{\mathrm{h}} 1$-dominated results in the release of $\mathrm{T}_{\mathrm{h}} 1$-related cytokines such as TNF and IFN $\gamma$. Allergy and asthma on the other hand are $\mathrm{T}_{\mathrm{h}} 2$-dominated and patients with coexisting allergies might have elevated levels of IL-4, IL-5 and IL-13 in sera. If cytokines are used as markers for $\mathrm{T}_{\mathrm{h}} 1 / \mathrm{T}_{\mathrm{h}} 2$ dominance, they should preferably be measured directly in the tissue where the cytokines are released and not systemically in the circulation.

We found a dominance of $\operatorname{IgG}_{1}$ in type 1 diabetic and LADA patients, and this is likely to reflect a dominant $T_{h} 1$ response against $G_{A D}$ in pancreatic tissue. Differences in IgG-subclass distribution against GADA and IA-2A among patients with type 1 diabetes have been reported and $\mathrm{IgG}_{1}$ is the most frequently occurring subclass in all studies so far $[8,13,19,21$, 22]. However, little is known about the IgG-subclasses in patients not classified as type 1 diabetic. The lev- 
el of $\mathrm{IgG}_{3}$ varies considerably between studies, which could be partly explained by the fact that this subclass is not as stable as the other subclasses. In vivo $\operatorname{IgG}_{1}$, $\mathrm{IgG}_{2}$ and $\mathrm{IgG}_{4}$ circulate for about 21 days while $\mathrm{IgG}_{3}$ degrades after about 7 days. The handling time of the sample could vary and influence the level of $\mathrm{IgG}_{3}$ to a greater degree than for the other subclasses.

Even if the $T_{h} 1 / T_{h} 2$ paradigm were an oversimplification $[23,24]$, it is highly likely that $T_{h} 1$ cells and their related cytokines accelerate the destruction of pancreatic beta cells. Some studies have suggested that the $T_{h} 2$ profile in some way is protective against the aggressive damage inflicted on the insulin-producing cells [25, 26, 27, 28, 29]. Furthermore, in our study the LADA patients, who expressed more $\mathrm{IgG}_{4}$, also had better preserved beta cell function at clinical onset. Of course, this could be because patients with LADA have higher expression of $\mathrm{T}_{\mathrm{h}} 2$ cytokines in the pancreatic tissue, not high enough to be entirely protected but sufficient to slow down progression to beta cell failure. It is still unclear whether the presence of $\mathrm{IgG}_{4}$ predicts better preserved beta cell function in LADA patients in the time after clinical onset, and further studies will be needed to clarify this.

We conclude that in some patients with LADA the presence of the $\mathrm{IgG}_{4}$-subclass against $\mathrm{GAD}_{65}$ is an indication of a more balanced immune response in the pancreatic tissue. The dominance of $\operatorname{IgG}_{1}$ in type $1 \mathrm{di}$ abetes represents a more aggressive $\mathrm{T}_{\mathrm{h}} 1$-dominated reaction.

Acknowledgements. This study was funded by the Swedish Medical Research Council (K97-19x-12242-01A), funds from Region Skåne and the University of Lund (ALF), Stig Almén's Foundation and the Juvenile Diabetes Foundation / Wallenberg Foundation. We are grateful to Birgitte Ekholm, Malin Johannesson and Ulrika Olsson for excellent technical assistance.

\section{References}

1. Törn C, Landin-Olsson M, Östman J et al. (2000) Glutamic acid decarboxylase antibodies (GADA) is the most important factor for prediction of insulin therapy within 3 years in young adult diabetic patients not classified as Type $1 \mathrm{di}-$ abetes on clinical grounds. Diabetes Metab Res Rev 16:442-447

2. Carlsson A, Sundkvist G, Groop L, Tuomi T (2000) Insulin and glucagon secretion in patients with slowly progressing autoimmune diabetes (LADA). J Clin Endocrinol Metab $85: 76-80$

3. Törn C, Gupta M, Nikitina Zake L, Sanjeevi CB, LandinOlsson M (2003) Heterozygosity for MICA5.0/MICA5.1 and HLA-DR3-DQ2/DR4-DQ8 are independent genetic risk factors for latent autoimmune diabetes in adults. Hum Immunol 64:902-909

4. Tuomi T, Carlsson A, Li H et al. (1999) Clinical and genetic characteristics of type 2 diabetes with and without GAD antibodies. Diabetes 48:150-157

5. Hagopian WA, Sanjeevi CB, Kockum I et al. (1995) Glutamate decarboxylase-, insulin-, and islet cell-antibodies and
HLA typing to detect diabetes in a general populationbased study of Swedish children. J Clin Invest 95:15051511

6. Turner R, Stratton I, Horton V et al. (1997) UKPDS 25: autoantibodies to islet-cell cytoplasm and glutamic acid decarboxylase for prediction of insulin requirement in type 2 diabetes. UK Prospective Diabetes Study Group. Lancet 350:1288-1293

7. Bonifacio E, Scirpoli M, Kredel K, Fuchtenbusch M, Ziegler AG (1999) Early autoantibody responses in prediabetes are IgG1 dominated and suggest antigen-specific regulation. J Immunol 163:525-532

8. Couper JJ, Harrison LC, Aldis JJ, Colman PG, Honeyman MC, Ferrante A (1998) IgG subclass antibodies to glutamic acid decarboxylase and risk for progression to clinical insulin-dependent diabetes. Hum Immunol 59:493-499

9. Schmid S, Molteni A, Fuchtenbusch M, Naserke HE, Ziegler AG, Bonifacio E (2002) Reduced IL-4 associated antibody responses to vaccine in early pre-diabetes. Diabetologia 45:677-685

10. Hawa MI, Fava D, Medici F et al. (2000) Antibodies to IA2 and GAD65 in type 1 and type 2 diabetes: isotype restriction and polyclonality. Diabetes Care 23:228-233

11. Koczwara K, Schenker M, Schmid S, Kredel K, Ziegler AG, Bonifacio, E (2003) Characterization of antibody responses to endogenous and exogenous antigen in the nonobese diabetic mouse. Clin Immunol 106:155-162

12. Mosmann TR, Sad S (1996) The expanding universe of T-cell subsets: Th1, Th2 and more. Immunol Today 17: 138-146

13. Petersen JS, Kulmala P, Clausen JT, Knip M, Dyrberg T (1999) Progression to Type 1 diabetes is associated with a change in the immunoglobulin isotype profile of autoantibodies to glutamic acid decarboxylase (GAD65). Childhood Diabetes in Finland Study Group. Clin Immunol 90:276-281

14. Romagnani S (1996) Th1 and Th2 in human diseases. Clin Immunol Immunopathol 80:225-235

15. Grubin CE, Daniels T, Toivola B et al. (1994) A novel radioligand binding assay to determine diagnostic accuracy of isoform-specific glutamic acid decarboxylase antibodies in childhood IDDM. Diabetologia 37:344-350

16. Verge CF, Stenger D, Bonifacio E et al. (1998) Combined use of autoantibodies (IA-2 autoantibody, GAD autoantibody, insulin autoantibody, cytoplasmic islet cell antibodies) in Type 1 diabetes: Combinatorial Islet Autoantibody Workshop. Diabetes 47:1857-1866

17. Törn C, Landin-Olsson M, Scherstén B (2001) Predictability of C-peptide for autoimmune diabetes in young adult diabetic patients. Pract Diab Int 18:83-88

18. Seissler J, Eikamp K, Schott M, Scherbaum WA (2002) IA-2 autoantibodies restricted to the IgG4 subclass are associated with protection from Type 1 diabetes. Horm Metab Res 34:186-191

19. Ng WY, Lui KF, Cheah JS, Thai AC (2002) IgG1 subclass dominates autoimmune response to tyrosine phosphataselike molecule IA-2 in Chinese Type 1 diabetes patients. Horm Metab Res 34:596-600

20. Kero J, Gissler M, Hemminki E, Isolauri E (2001) Could TH1 and TH2 diseases coexist? Evaluation of asthma incidence in children with coeliac disease, Type 1 diabetes, or rheumatoid arthritis: a register study. J Allergy Clin Immunol 108:781-783

21. Ng WY, Thai AC, Lui KF, Yeo PP, Cheah JS (1999) Systemic levels of cytokines and GAD-specific autoantibodies isotypes in Chinese IDDM patients. Diabetes Res Clin Pract 43:127-135 
22. Kasuga A, Shimada A, Ozawa Y, Maruyama T, Oya K, Saruta T (2000) IgG1 is the dominant subclass of antibody against glutamic acid decarboxylase among Type 1 diabetes in Japanese. Endocr J 47:57-62

23. Rook G (2001) Th1- or Th2-cell commitment during infectious disease: an oversimplification? Trends Immunol 22:481-482

24. Sheikh A, Smeeth L, Hubbard R (2003) There is no evidence of an inverse relationship between $\mathrm{TH} 2$-mediated atopy and TH1-mediated autoimmune disorders: Lack of support for the hygiene hypothesis. J Allergy Clin Immunol 111:131-135

25. Feili-Hariri M, Falkner DH, Gambotto A et al. (2003) Dendritic cells transduced to express interleukin-4 prevent diabetes in nonobese diabetic mice with advanced insulitis. Hum Gene Ther 14:13-23
26. Yang Z, Chen M, Wu R et al. (2002) Suppression of autoimmune diabetes by viral IL-10 gene transfer. J Immunol 168:6479-6485

27. Cameron MJ, Arreaza GA, Zucker P et al. (1997) IL-4 prevents insulitis and insulin-dependent diabetes mellitus in nonobese diabetic mice by potentiation of regulatory $\mathrm{T}$ helper-2 cell function. J Immunol 159:4686-4692

28. Kukreja A, Maclaren NK (2000) Current cases in which epitope mimicry is considered as a component cause of autoimmune disease: immune-mediated (type 1) diabetes. Cell Mol Life Sci 57:534-541

29. Petrovsky N, Silva D, Schatz D (2003) Vaccine therapies for the prevention of Type 1 diabetes mellitus. Paediatr Drugs 5:575-582 